\title{
Teacher e-Training and Student e-Learning during the Period of Confinement Caused by Covid-19 in Case of Morocco
}

\author{
Abdessamad El Omari ${ }^{1}$ \\ Laboratory of Physical Chemistry of \\ Materials, Faculty of Sciences Ben \\ M'Sick, Hassan II Universityline \\ Casablanca, Morocco
}

\author{
Malika Tridane ${ }^{2}$ \\ Regional Center of Education and \\ Formation in Professions \\ Boulevard Bir-Anzarane Anfa \\ Casablanca, Morocco
}

\author{
Said Belaaouad ${ }^{3}$ \\ Laboratory of Physical Chemistry of \\ Materials, Faculty of Sciences Ben \\ M'Sick, Hassan II Universityline \\ Casablanca, Morocco
}

\begin{abstract}
The rapid advance of the new coronavirus imposes several drastic measures on the authorities to contain the virus and prevent its spread. The Ministry of Education has decreed the suspension of face-to-face classes in all schools. The pedagogical continuity, now a priority, must be carried out remotely through video conferencing, platforms, video capsules The main questions of this research are: What are the success factors of distance learning and training in Moroccan context? This raises a whole range of questions: are teachers able to adopt this new teaching method? Are the means available and adequate to ensure distance learning? What about the training of teachers to cope with this unexpected radical change? Based on the results obtained from a population of 126 teachers, we discovery that 91\% of teachers said that they have adopted the online teaching but it is not really e-learning as recognized by the specialists, its objective is rather to maintain communication with the students. While 9\% have not used this mode of teaching, they point out that this type of teaching does not guarantee equal opportunities for learners. We have therefore concluded that the necessary material resources must be made available to ensure the success of this type of teaching, such as computers and the Internet, as well as the necessary training for teachers to develop their skills associated with managing distance learning.
\end{abstract}

Keywords-COVID-19; e-learning; e-training; change; innovation

\section{INTRODUCTION}

Morocco, like other countries in the world, experienced a crisis due to the spread of the COVID-19 epidemic in early March 2020.

In order to control this situation, the government has taken a series of decisions by stopping air traffic in order to isolate the country and control internal and incoming infected cases before stopping the movement of airports.

It also closed all places that could contribute to the spread of this epidemic. With the increasing number of infections announced by official communications from the Ministry of Health, the decision of containment has been taken, preventing citizens from leaving their homes except for the most urgent needs.

These prevention measures affected all vital areas; the education and training sector was no exception. The Ministry of
National Education, Vocational Training, Higher Education and Scientific Research (MNEVTHESR) suspended face-to-face classes in order to prevent the spread of this epidemic in schools [1].

To ensure pedagogical continuity, the MNEVTHESR launched a communiqué encouraging teachers to adopt distance learning [2], which is not obvious since there was no prior preparation to guarantee the success of this change.

Problematic: The adoption of distance learning leads us to ask this main question: What are the success factors of distance learning and training in Moroccan context? This raises a whole range of questions: How were teachers able to deal with this situation that arose? Did they receive appropriate support to migrate to e-learning? Did they engage in this new teaching modality? How satisfied are they? And what is their attitude towards e-training and e-learning?

The answer to all these questions will help us to achieve the objective of our study.

Purpose of the study: The main aim of this study is to define factors for success of e-training and e-learning, while determining the causes behind the limited use of these modes of training and teaching, whether teachers engage in e-learning, their attitudes towards this type of training and their feelings about his impact on their teaching practices and determining the constraints of such training.

\section{THEORETICAL BACKGROUND}

New technologies for processing, sharing and using information are emerging day by day. The field of learning is also beginning to change its approach and method with the integration of these new technologies, first, by complementing the classical models, by integrating these technologies into classroom practices, and why not replace them later, by adopting online teaching [3].

The subject of the adoption of information and communication technologies in education and especially in training and e-learning, has given rise to a number of theories, concepts and standards, which aim at understanding and analyzing the factors that influence the acceptability and implementation of this technological innovation. 
Among these theories are Fishbein and Ajzen's theories of reasoned action and planned behavior [4], Davis's Model of Technology Acceptance (MTA) [5], Brangier's symbiotic model [6], and Ram's theory of resistance to innovation [7]. These theories might help us to understand the factors that can impact the success of e-learning and e-training.

The narrow scope of this research does not allow us to address them in detail. On the other hand, the presentation of two fundamental concepts is necessary: e-training and elearning.

\section{A. e-Learning}

Oxford dictionary define e-learning as "a system of learning that uses electronic media, typically over the internet". Bowles and al. considers it as "encompasses any type of learning content that is delivered electronically" [8]. Hoppe and al. considers elearning as "a learning supported by digital electronic tools and media" [9]. All these definitions focus on the idea of using electronic tools and media, but there are other dimensions to this teaching practice. for Abrami and al. e-learning is "the development of knowledge and skills through the use of information and communication technologies (ICTs), particularly to support interactions for learning - interactions with content, with learning activities and tools, and with other people" [10].

This definition underlines the interaction aspects of the elearning process. The student is therefore not only a passive receiver.

\section{B. e-Training}

Before defining e-training we must present a definition of training. McClelland defined it as "an activity that changes people's behaviors in an organization. Increased productivity is meant to be the most important reason for training" [11].

E-training is defined as "Training delivered through the electronic means, which could be Web-based training programs and activities" [12]. It is also defined as "a separation of trainer from trainee and part of teaching and training through instruction, observations, or processes focused on providing needed skills and knowledge to meet immediate business goals" [13].

So, the e-training concept in our study is defined as using ICT to develop teachers' knowledge and skills and change their behaviors related to teaching practices in dedicated online teaching environments.

\section{Challenges of e-training and e-learning}

The operationalization of these concepts has given rise to reflection on issues and challenges of the implementation of online teaching and training practices. Mueen Mohsin and al listed six main issues and challenges which are: lack of awareness, low adoption rate, band width issue and connectivity, language barrier, difficult in engaging learners online, and lastly computer literacy and digital divide [14]. These challenges will increase especially with the conditions of the Covid 19 pandemic.

\section{MATERIALS AND METHODS}

\section{A. The Sample}

The empirical part of this study is based on a survey of 126 teachers from different regions and different levels (primary, secondary college and qualifying) during the confinement period from March 16 to June 30, 2020. The selection of the sample was done in a simple random way, as we randomly selected the people to answer our survey. The proportion is 42 women and $84 \mathrm{men}$. The other characteristics are presented in the following Table I as follows.

TABLE I. PRESENTS THE Age OF THE SAMPLE

\begin{tabular}{|c|c|c|c|c|c|c|}
\hline \multirow{3}{*}{$\begin{array}{l}\text { Genre } \\
\text { Men }\end{array}$} & \multicolumn{6}{|c|}{ Age } \\
\hline & \multicolumn{2}{|c|}{$<36$ years } & \multicolumn{2}{|c|}{$36 y$ to $45 y$} & \multicolumn{2}{|c|}{$>45$ years } \\
\hline & 38 & $30 \%$ & 28 & $22 \%$ & 18 & $14 \%$ \\
\hline Women & 19 & $15 \%$ & 16 & $13 \%$ & 7 & $06 \%$ \\
\hline Total & 57 & $45 \%$ & 44 & $35 \%$ & 25 & $20 \%$ \\
\hline
\end{tabular}

Table II shows the seniority of the sample.

TABLE II. SENIORITY OF THE SAMPLE

\begin{tabular}{|c|c|c|c|c|c|c|}
\hline \multirow{3}{*}{$\begin{array}{l}\text { Genre } \\
\text { Men }\end{array}$} & \multicolumn{6}{|c|}{ Seniority } \\
\hline & \multicolumn{2}{|c|}{ <11years } & \multicolumn{2}{|c|}{$11 y$ to $15 y$} & \multicolumn{2}{|c|}{$>15$ years } \\
\hline & 45 & $36 \%$ & 10 & $08 \%$ & 29 & $23 \%$ \\
\hline Women & 26 & $21 \%$ & 2 & $02 \%$ & 14 & $10 \%$ \\
\hline Total & 71 & $57 \%$ & 12 & $10 \%$ & 43 & $43 \%$ \\
\hline
\end{tabular}

Table III shows the location of the establishment of our sample.

TABLE III. ENVIRONMENT OF THE ESTABLISHMENT

\begin{tabular}{|l|l|l|l|l|l|l|}
\hline \multirow{2}{*}{ Genre } & \multicolumn{6}{l}{ Environment of the establishment } \\
\cline { 2 - 7 } & \multicolumn{2}{|l|}{ Urban } & \multicolumn{2}{l|}{ Periurban } & \multicolumn{2}{l|}{ Rural } \\
\hline Men & 40 & $32 \%$ & 18 & $14 \%$ & 26 & $21 \%$ \\
\hline Women & 29 & $23 \%$ & 9 & $07 \%$ & 4 & $03 \%$ \\
\hline Total & 69 & $55 \%$ & 27 & $21 \%$ & 30 & $24 \%$ \\
\hline
\end{tabular}

Table IV shows the teaching level of our sample.

TABLE IV. TEACHING LEVEL

\begin{tabular}{|c|c|c|c|c|c|c|}
\hline \multirow{3}{*}{$\begin{array}{l}\text { Genre } \\
\text { Men }\end{array}$} & \multicolumn{6}{|c|}{ Teaching level } \\
\hline & \multicolumn{2}{|c|}{ primary } & \multicolumn{2}{|c|}{ Middle school } & \multicolumn{2}{|c|}{ Highschool } \\
\hline & 46 & $37 \%$ & 11 & $09 \%$ & 27 & $21 \%$ \\
\hline Women & 23 & $18 \%$ & 05 & $04 \%$ & 14 & $11 \%$ \\
\hline Total & 69 & $55 \%$ & 16 & $13 \%$ & 41 & $32 \%$ \\
\hline
\end{tabular}

B. Data Collection Tool

The data collection tool used to conduct this study is an online survey that is composed of three parts:

- The first one contains general information about the sample. 
- The second one is about teacher e-training:

- The existence of e-training courses for teachers;

○ Participation in e-training courses;

- Reasons for not taking advantage of e-training courses;

- Avenues for the development of distance e-training for teachers;

- The third concerns the adoption of e-learning by teachers:

- The performance of teachers during the e-learning process and their degree of satisfaction;

o Reasons why teachers have not all adopted elearning.

\section{RESULTS ANDDISCUSSION}

In this part, we will propose an analysis of the responses of our sample according to two main axes: e-training and elearning.

\section{A. e-Training}

At first, we will see if the teachers have an idea about the existence of distance training for teachers on the internet. $52 \%$ say there are online training courses. While $48 \%$ have no idea about the offer of online training. However, half of 52\% did not receive any training during this period of confinement. This means that only $26 \%$ of all sample have benefited from online training but $74 \%$ of teachers have not benefited from online training. This prompts us to look for the causes behind this situation, otherwise why teachers have not taken online training? The results are presented as follow in Table V.

TABLE V. REASONS FOR NOT FOLLOWING E-TRAINING COURSES

\begin{tabular}{|l|l|}
\hline Reasons for not following e-training courses & Frequency \\
\hline I did not find these courses & $38 \%$ \\
\hline I was not asked to participate & $39 \%$ \\
\hline I didn't look for these courses & $23 \%$ \\
\hline I don't need this training & $05 \%$ \\
\hline $\begin{array}{l}\text { I find that I don't have the necessary skills to follow these } \\
\text { courses. }\end{array}$ & $15 \%$ \\
\hline My prerequisites are insufficient to follow these courses. & $37 \%$ \\
\hline
\end{tabular}

For those teachers who have attended e-training courses, has it had an impact on their practices? We have proposed this question as a Likert scale, it quantifies the qualitative information may result in a score. The results are presented as follow in Fig. 1.

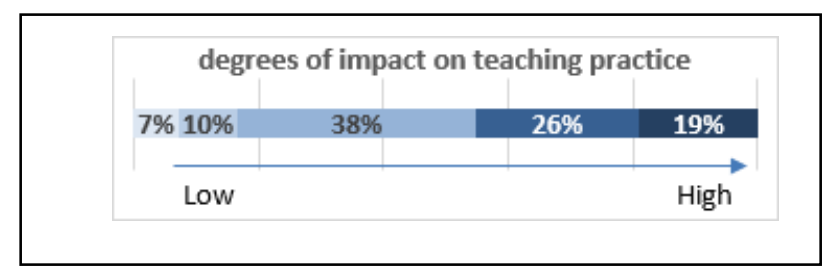

Fig. 1. Degree of Impact on Teaching Practice.
Almost half of interviewees $45 \%$ feel significant impact of training on teaching practices. The other half, on the other hand, see little impact.

These data prompted us to ask a legitimate question: why do e-training courses have a limited impact on improving teaching practices?

The results are shown in Fig. 2.

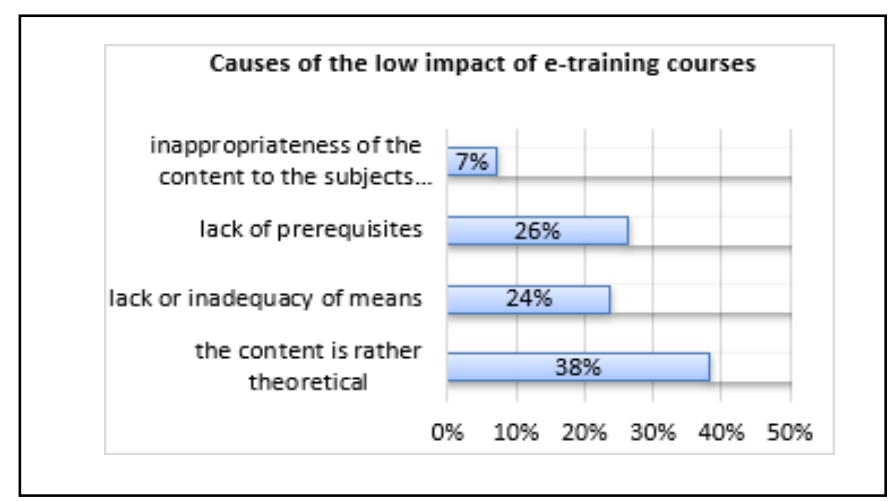

Fig. 2. Causes of the Low Impact of e-training Courses.

A simple reading of the answers to these questions reflects the need to review the engineering of these training courses and relate them to the actual needs of teachers. The introduction of e-training must be accompanied by a paradigm shift in attitudes, pedagogical concepts and instructional engineering practices [15]. It must also promote a better balance between theoretical knowledge and those acquired in practical environment [16].

In order to have a positive impact of the training courses, we need to know what kind of form do teachers prefer?

The results are presented in the Table VI.

TABLE VI. MODE OF TRAINING

\begin{tabular}{|l|l|}
\hline Mode of training & Frequency \\
\hline Hybrid Training & $57 \%$ \\
\hline Online training & $11 \%$ \\
\hline Analysis of practices & $39 \%$ \\
\hline Face-to-face training & $48 \%$ \\
\hline Training through coaching & $30 \%$ \\
\hline
\end{tabular}

From the percentages obtained it seems clear that teachers are not very interested to online learning. On the other hand, they are rather inclined to other forms of training.

\section{B. e-Learning}

The lack of teacher training and support has had an impact on the adoption of e-learning and the quality of this modality.

For the adoption of e-learning with students during confinement, the results are as follow in Fig. 3.

Only $9 \%$ have not used this mode of teaching, while $91 \%$ of teachers said that they have adopted it. But can we talk really about e-learning where the teacher has a platform dedicated to this type of teaching? 


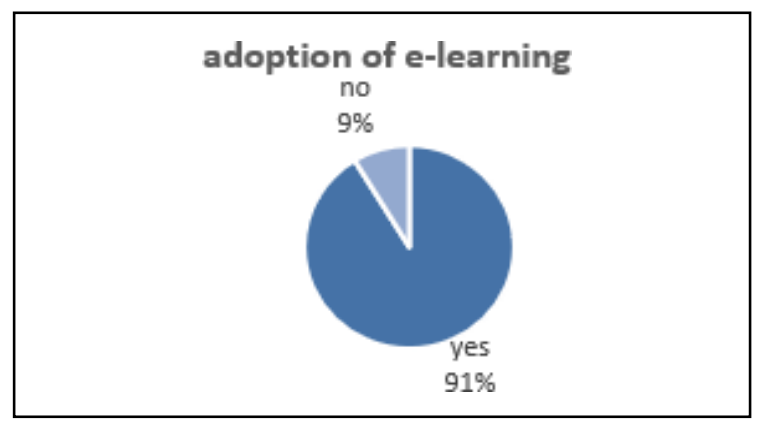

Fig. 3. Levels of Teacher's Satisfaction.

Understanding the quality of this type of teaching has led us to ask two questions; the first concerns the means used and the second concerns measuring the degree of satisfaction of teachers.

The answer of the first question is shown in Table VII.

TABLE VII. THE MEANS ADOPTED DURING E-LEARNING

\begin{tabular}{|l|l|}
\hline The means adopted & Frequency \\
\hline Social networks & $88 \%$ \\
\hline Videoconferencing tools & $13 \%$ \\
\hline Microsoft-Teams platform recommended by the Ministry & $22 \%$ \\
\hline
\end{tabular}

The most widely used means are social networks, this shows that the main aim is to maintain communication with students more than e-learning itself. Just $22 \%$ of teachers have used Microsoft-teams platform for this mode of teaching.

To measure the degree of satisfaction we used a question with the Likert scale. The results are presented in Fig. 4.

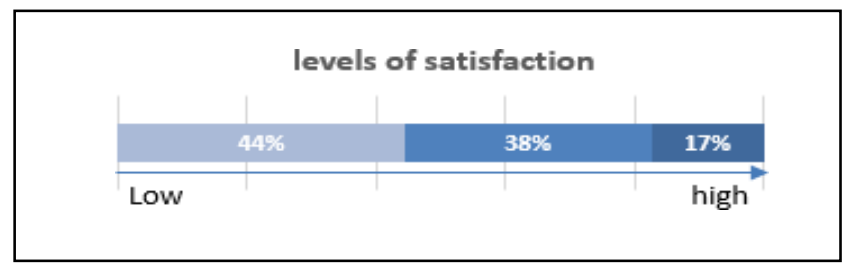

Fig. 4. Adoption of e-learning.

Only $17 \%$ of teachers expressed satisfaction. While $44 \%$ are dissatisfied.

The reasons for dissatisfaction for those who have adopted this modality are presented in Table VIII.

TABLE VIII. REASONS FOR TEACHER DISSATISFACTION

\begin{tabular}{|l|l|}
\hline Reasons for dissatisfaction & Frequency \\
\hline Unsatisfactory capacity of teachers to use the platforms. & $12 \%$ \\
\hline Unsatisfactory ability of students to use the platforms. & $37 \%$ \\
\hline The low quality of the means and tools used by teachers. & $36 \%$ \\
\hline The low quality of the means and tools used by students. & $54 \%$ \\
\hline Not all students have access to e-learning. & $81 \%$ \\
\hline
\end{tabular}

Even if Morocco has mobilized since 2004 to set up a national strategy for integrating information and communication technologies into the educational process [17]. we see that there is still a lack of access to technological tools either for teachers or for students. There are hidden digital differences that impede equal access to digital resources for all learners [18]. There is a lack of home computer access $61.5 \%$, lack of computer training $70.4 \%$ and Absence of oriented use (research activities, exercises, courses, etc.) [19].

Almost all of teachers who did not use e-learning argue that the lack of equitable access to e-learning for learners makes its implementation practically impossible.

\section{CONCLUSION}

This study shows us that most of our population $(91 \%)$ adopts e-learning, but it is not really e-learning as the specialists recognize, it is rather aimed at maintaining communication with the students. While a minority (9\%) has not adopted this mode of teaching, their pretext is that this type of teaching does not guarantee equal opportunities for learners.

We have concluded that the success of this type of teaching implies the provision of the necessary material resources, such as computers and the Internet, to teachers and students, as well as the necessary training for teachers to develop their skills related to the management of e-learning.

\section{RECOMMENDATIONS}

The success of distance learning and training in the Moroccan context requires a change in teacher's representations and perceptions of these modes of work. This change must be accompanied by responsible for education and training, with a view to ensuring the optimum conditions, namely: a careful analysis of teacher's needs in order to design quality training arrangements focusing more on the practical side and the provision of teachers and students with equipment and resources that can improve this teaching and training method.

Several digital and hybrid methods can be taken into consideration which makes it possible to improve the quality of teaching-learning in the context of online training.

We can use the work of Daaif in 2019 that developed applications for the simulation of practical work in geometric crystallography as well as other applications for modeling chemical reactions by the Monte-Carlo method in kinetics [2021-22].

\section{VII.LIMITATIONS}

The limitations of this study include:

- The limited number of the target population which does not allow for generalizing the results of this research.

- Also, the online questionnaires do not guarantee the credibility of the answers of the members of the target population, but the studies conducted in this field (in Moroccan context) confirm the results obtained by the present research. 


\section{REFERENCES}

[1] Ministerial announcement concerning the interruption of face-to-face courses and their replacement by distance courses.

[2] Guidance Note on the Response of Education Systems to COVID19. March 25, 2020.

[3] J. Muftisada, J. Daaif, M. Tridane S. Belaaouad "Use of smartphones in learning and techno-pedagogical integration of artificial intelligence tools as a prospect for intelligent learning: Case of Moroccan students from Hassan II University of Casablanca" Available Online at http://www.warse.org/IJETER/static/pdf/file/ijeter252892020.pdf. https://doi.org/10.30534/ijeter/2020/252892020 ISSN 2347 - 3983, International Journal of Emerging Trends in Engineering Research Volume 8. No. 9, 6496-6504, September 2020.

[4] Ajzen. I., Fieshbein. M., (1975), "Belief, attitude, intention and behavior ", edition Addison Wesley.

[5] Davis, F. D. (1989). Perceived Usefulness, Perceived Ease of Use, and User Acceptance of Information Technology. MIS Quarterly, 13(3), 319. doi: $10.2307 / 249008$.

[6] Éric Brangier, Aude Dufresne, Sonia Hammes-Adelé " Symbiotic approach to the human-technology relationship: perspectives for computer ergonomics " Le Travail Humain, tome 72, no 4/2009, 333353.

[7] Ram Sudha, "A model of innovation resistance ", In Advances in Consumer Research, $\mathrm{n}^{\circ} 14,1987$, p. 208-212.

[8] Bowles, M. 2004. Relearning to e-learn: Strategies for electronic learning and knowledge. Melbourne University Publishing.

[9] H.U. Hoppe , R. Joiner, M. Milrad \& M. Sharples, Guest editorial: Wireless and Mobile Technologies in Education, Journal of Computer Assisted Learning (2003) 19, 255-259'.

[10] Abrami, P., Bernard, R., Wade, A, Borokhovski, E., Tamin, R., Surkes, M., and Zhang, D. (2008). A review of e-learning in Canada: Rejoinder to commentaries. Canadian Journal of Learning and Technology, 32(3), p. 30 .

[11] McClelland, S.D. 2002. A training needs assessment for the united way of dunn county wisconsin. University of Wisconsin.

[12] https://www.igi-global.com/dictionary/does-learning-improvecommunication-among/8945.

[13] Echard, R.D. and Z.L. Berge, 2008. Quality management builds solid etraining. Administering examinations for quality control in distance education: The National Open University of Nigeria Perspective EC IBARA.

[14] Mueen Mohsin , Rosnafisah Sulaiman , a study on e-training adoption for higher learning institutions, International Conference on Teaching and Learning in Education, 2013, International Journal of Asian Social Science, 2013, 3(9):2006-2018.

[15] M.Bassiri, M.Radid, and S. Belaaouad "Modeling of the TeachingLearning Process in E-Learning" K29959_C002.indd, Shaping the Future of ICT, 07-06-2017, Page 15-40, (2017).

[16] A.El yadari, M.Tridane, M.Radid ,S.Belaaouad "Engineering of a training program for future teachers based on information and communication technologies" International Journal of Advanced Trends in Computer Science and Engineering. http://www.warse.org/IJATCSE/static/pdf/file/ijatcse4681.42019.pdf https://doi.org/10.30534/ijatcse/2019/4681.42019.

[17] Mazouak A., " Modeling of Digital Media in The Management of Educational Performance in Morocco School's" Iraqi Journal of Science, 2021, Special Issue, pp: 17-23 DOI: 10.24996/ijs.2021.SI.1.3.

[18] O.Dardary, J.Daaif, M.Tridane, S.Belaaouad "Distance learning in the age of covid - 19: between perspective and reality " International Journal of Engineering Applied Sciences and Technology, Published Online September 2020 in IJEAST (http://www.ijeast.com) Vol. 5, Issue 5, ISSN No. 2455-2143, Pages 46-52, 2020.

[19] O.Dardary, Z.Azar, M.Tridane, S. Belaaouad "Engineering of a Training Device and Skills Through the Integration of New Information and Communication Technologies in the Field of Exact Sciences" International Journal of Advanced Trends in Computer Science and Engineering http://www.warse.org/IJATCSE/static/pdf/file/ijatcse4581.42019.pdf https://doi.org/10.30534/ijatcse/2019/4581.42019.

[20] Daaif J., Zerraf S., Tridane M., Benmokhtar S., Belaaouad S. (2019a). Pedagogical engineering to the teaching of the practical experiments of chemistry: Development of an application of three-dimensional digital modelling of crystalline structures. Cogent Education, 2019, 6(1), 1708651. DOI: https://doi.org/10.1080/2331186X.2019.1708651.

[21] J. Daaif, S. Zerraf, M. Tridane, S. Benmokhtar, S. Belaaouad. (2019b). Technological Innovation in Teaching and Research in Chemical Science: Development of a Computer Application for the Simulation of the Practical Works of Crystallography. International Journal of Recent Technology and Engineering (IJRTE) ISSN: 2277-3878, Volume-8 Issue-3.

[22] Daaif, J., Zerraf, S., Tridane, M., El Mahi Chbihi, M., Moutaabbid, M., Benmokhtar, S., Belaaouad, S. (2019c). Computer simulations as a complementary educational tool in practical work: Application of monte- carlo simulation to estimate the kinetic parameters for chemical reactions. International Journal of Advanced Trends in Computer Science and Engineering, 8(1.4 S1), pp. 249-254. https://doi.org/10.30534/ijatcse/2019/3881.42019. 